\title{
The Bologna Process in Higher Education of Belarus
}

\author{
Larysa Sliapniova \\ Belarusian National Technical University \\ Minsk, Belarus \\ E-mail: slpnv@mail.ru
}

\author{
Alexander Tsyganov \\ Belarusian National Technical University \\ Minsk, Belarus
}

\begin{abstract}
Belarus joined the Bologna process in spring 2015, which called for the need to converge higher education systems of Belarus and countries of the European Higher Education Area. Higher Education systems in different countries are brought to standard in several ways. The member states of the Bologna process are invited to introduce a single system of qualifications and degrees targeted to the modern job market. To ensure comparing the study attainment and performance of students across different higher education institutions a system of credits is introduced. The Bologna process also provides much more independence of higher education institutions when compared to the existing system. Becoming engaged in the Bologna process Belarus takes obligations to reform the higher education system to bring it closer to a European standard.
\end{abstract}

Keywords-Bologna process; Higher Education in Belarus; grading system

\section{INTRODUCTION}

On June 19, 1999 in Bologna, Italy, a Declaration of the European Higher Education Area was signed. About 30 countries agreed to approve the Declaration. It was preceded by the Sorbonne declaration signed by Education ministers of four leading countries of Europe [1]. The declaration's goal was to bring European higher education to a standard [2].

Bologna process is meant to ensure a more comparable and compatible system of higher education in Europe with the objective of creating a single European Higher Education Area [3].

By the time the document was issued, the European Union had a single market of highly mobile and skilled professionals, particularly among young people [4]. This called for the need to adopt standards of transnational education, standardize curriculum for different branches of study, and adopt a single system of qualifications and degrees focused on the modern job market. Besides, comparability and compatibility of higher education ensured free movement of students during their studies and professors, who could improve academically and professionally [5].

\section{EUROPEAN CREDIT TRANSFER AND ACCUMULATION SYSTEM}

To ensure that higher education levels were even across member states, higher education institutions implemented the
European Credit Transfer and Accumulation System (ECTS). The system's main objective is to mutually recognize qualifications obtained in different higher education institutions by common way of assessment and comparability of academic records of students and the transfer of credits from one institution to another. ECTS is the system, which takes account of all the students' activities within the so-called workload.

The workload includes:

- Time in the institution: lectures, practical work, laboratory work, etc. For example, for one 2 hours-aweek course in a semester a learner gets 2 credits;

- Time for self-study. This assessment is relative, because it estimates how much time it takes a student to prepare a report on the average, and not how long it actually took him;

- Time to read recommended literature and make notes;

- Time to prepare written papers and prepare for examinations.

Considering that an academic year is 40 weeks long ( 6 of which are reserved for two examination sessions), a learner is required to obtain 60 ECTS-credits in one academic year, which includes about 1500 to 1800 academic hours in total on a variety of disciplines. The Bologna process includes both core curriculum and some special courses students can choose from (approx. 30\%). In Belarus, until quite recently, students did not have a chance to choose their own courses.

A higher education system includes two basic cycles: undergraduate and graduate. The first cycle is terminated by obtaining a Bachelor's degree and the second one by Master's degree. Sometimes a third cycle is included; it is associated with independent research in a particular scientific field and obtaining a PhD (Doctor of Philosophy) degree.

To obtain a Bachelor's degree a learner should have 180 to 240 ECTS-credits and needs at least 3 years. To obtain a Master's degree a learner should have the number of credits he lacks to achieve the total amount of 300 ECTS-credits for two cycles (which means another 60 to 120 ECTS-credits in the second cycle). It would take him another 1 or 2 years. The system of ECTS-credits does not specify the contents or methods used in individual courses. It is used to assess the workload of a course and is not directly connected with the assessment of knowledge a learner gains. Although the credit 
award system can vary significantly in different institutions, in general, ECTS-credits allow comparability and credit transfer between a variety of higher education institutions. The Bologna process is a dynamic system, which keeps progressing and getting deeper [6].

\section{GRADING SYSTEM IN BELARUS}

In 2002, a ten-point grading system was introduced in Belarus for knowledge assessment in schools categorized as vocational, trade, or higher education institutions.

TABLE I. QUANTITATIVE ASSESSMENT OF LEARNING ACTIVITIES

\begin{tabular}{|l|l|}
\hline \multicolumn{1}{|c|}{ Description } & \multicolumn{1}{c|}{ Grade } \\
\hline Unsatisfactory & 1 \\
\hline Almost satisfactory & 2 \\
\hline Satisfactory & 3 \\
\hline Fair & 4 \\
\hline Almost good & 5 \\
\hline Good & 6 \\
\hline Very good & 7 \\
\hline Almost excellent & 8 \\
\hline Excellent & 9 \\
\hline Outstanding & 10 \\
\hline
\end{tabular}

Grade 10. Outstanding. Free handling of educational material of any complexity with the use of knowledge from other courses or disciplines; ability to promptly and efficiently translate knowledge to solve problems in nonstandard situations; determination, responsibility, cognitive activity, and a creative attitude toward learning.

Grade 9. Excellent. Free handling of educational material of any complexity in an unfamiliar situation; fulfillment of a creative assignment; high level of self-sufficiency and extensive knowledge.

Grade 8. Almost excellent. Handling of educational material and its use in familiar and unfamiliar situations; minor single action-related errors that learners correct on their own; some experience of creative activity; conscientiousness, responsibility, self-judgment, selfreflection, etc.

Grade 7. Very good. Handling of educational material, including that of a various degree of complexity, its use in a familiar situation; minor single action-related errors; unassisted use of knowledge and skills of a special, academic and intellectual nature; tendency to creative transfer of knowledge, self-discipline, self-criticism, self-reflection, etc.

Grade 6. Good. Complete reproduction of educational material with minor errors; use of knowledge in a familiar situation according to an example; use of knowledge and skills of a special, academic and intellectual nature with minor aid from a professor; determination and intention to tackle problems; situational manifestation of a tendency to creativity.

Grade 5. Almost good. Conscious reproduction of educational material, including that of a various degree of complexity, with minor mistakes; difficulties in the use of some knowledge and skills of a special, academic and intellectual nature; interest in learning and reaching a result.

Grade 4. Fair. Mastering of educational material on a reproductive level and its incomplete reproduction; mistakes correctable when asking further (leading) questions; difficulties in use of knowledge or some skills of special, academic or intellectual nature; manifestation of volitional actions, interest to learning, adequate self-judgment, independent behavior, meaningfulness of actions, etc.

Grade 3. Satisfactory. Incomplete reproduction of educational material by memory only; major mistakes correctable by a professor; difficulties in use of knowledge of a special, academic and intellectual nature; intention to tackle problems; situational manifestation of responsibility, self-criticism.

Grade 2. Almost satisfactory. Recognition of the learning material, recognition of certain known terminology and facts; intention to tackle educational problems; situational interest to learning and discipline.

Grade 1. Unsatisfactory. Recognition of the learning material, differentiation of definitions, structural elements of knowledge, manifestation of volitional actions and motivation for learning.

Grade 0 . No reply or refused to reply $/ 7 /$.

In the existing ten-point grading system grade 0 is virtually not used. If a learner gets grade 1 to 3 , he needs to retake an exam or try to have credit awarded again. Grade 10 is hardly ever used.

\section{ECTS GRADING SCALE}

As the Bologna educational declaration does not regulate the grading system in each and every country, the majority of countries that are member states of a common European Higher Education Area combine their national grading systems with the ECTS grading system.

\section{A. Excellent (Outstanding).}

Theoretical part of the course is mastered completely, no knowledge gaps, the required practical skills of how to operate the material are built, all the study assignments within the program are completed, and performance is evaluated with a grade close to maximum.

\section{B. Very good (Excellent)}

Theoretical part of the course is completely mastered, no knowledge gaps, the required practical skills of how to operate the material are built for the most part, all the study assignments within the program are completed, and how the majority of assignments is completed is evaluated with a grade close to maximum.

\section{Good}

Theoretical part of the course is mastered completely, no knowledge gaps, some practical skills of how to operate the material are not formed completely, all the study assignment 
within the program are completed, none of the assignments is evaluated with a minimum grade, some of the assignments are completed with errors.

\section{Satisfactory}

Theoretical part of a discipline is mastered only in part, but knowledge gaps are not fatal, the required practical skills of how to operate the material are built for the most part, the majority of assignments within the program are completed, some of the completed assignments may contain errors.

\section{E. Unimpressive}

Theoretical part of the course is mastered only in part, some practical skills of how to operate the material are not formed, many assignments within the program are not completed, or how they are completed can be evaluated with a grade close to minimum.

Fx. Deemed unsatisfactory, with the right to retake an exam. Theoretical part of the course is mastered only in part, the required practical skills are not formed, the majority of assignments within the program is not completed or how they are completed is evaluated with a grade close to minimum; with further individual work it is possible to increase the quality of how assignments are fulfilled.

\section{F. Unconditionally unsatisfactory, without the right to retake an exam}

Theoretical part of the course is not mastered. The required practical skills are not formed, all the assignments contain major mistakes, and further individual work will not cause any significant increase in the quality of how the assignments are fulfilled.

ECTS-grades from A to E are awarded when a learner passes an exam, while grades Fx to $\mathrm{F}$ are awarded if a learner does not pass an exam [8].

The ECTS grading scale was developed to facilitate the transfer of grades from one higher education institution to another. It provides further information on the students' achievements, but does not substitute local grades. Higher Education Institutions take their own decisions on whether to use this grading system in their institutions [9].

\section{COMPARATIVE ANALYSIS OF EUROPEAN AND BELARUSSIAN GRADING SYSTEMS}

As Belarus is just on the road of adapting its own national grading system to the system used in Europe, below you can find only one of the options of juxtaposition of the grading system currently used in Belarus with the ECTSgrading system.
TABLE II.

\begin{tabular}{|c|c|c|c|}
\hline \multicolumn{2}{|c|}{ Local grading system } & \multicolumn{2}{|r|}{ ECTS-grading system } \\
\hline Grade & Description & Grade & Description \\
\hline 10 & Outstanding & $\mathrm{A}$ & $\begin{array}{l}\text { Excellent (excellent completion } \\
\text { within significant number of } \\
\text { errors) }\end{array}$ \\
\hline 9 & Excellent & \multirow[t]{2}{*}{ B } & \multirow{2}{*}{$\begin{array}{l}\text { Very good (higher than average } \\
\text { with a few errors) }\end{array}$} \\
\hline 8 & Very good & & \\
\hline 7 & Good & \multirow[t]{2}{*}{$\mathrm{C}$} & \multirow{2}{*}{$\begin{array}{l}\text { Good (correct completion in } \\
\text { general with some major } \\
\text { errors) }\end{array}$} \\
\hline 6 & Almost good & & \\
\hline 5 & Fair & $\mathrm{D}$ & $\begin{array}{l}\text { Satisfactory (not bad, but with } \\
\text { significant number of errors) }\end{array}$ \\
\hline 4 & Satisfactory & $E$ & $\begin{array}{l}\text { Unimpressive (performance } \\
\text { meets minimum criteria) }\end{array}$ \\
\hline 3 & \multirow{3}{*}{$\begin{array}{l}\text { Unsatisfactory } \\
\text { (with a } \\
\text { possibility to } \\
\text { retake an exam) }\end{array}$} & \multirow[t]{2}{*}{ Fx } & \multirow{2}{*}{$\begin{array}{l}\text { Unsatisfactory (with a } \\
\text { possibility to retake an exam) }\end{array}$} \\
\hline 2 & & & \\
\hline 1 & & $\mathrm{~F}$ & $\begin{array}{l}\text { Unsatisfactory (with the need } \\
\text { to retake full course) }\end{array}$ \\
\hline
\end{tabular}

\section{Higher EdUCATION IN BELARUS}

In Belarus there are 43 state and 9 private higher education institutions. A fundamental document, which gives the right to enter a higher education institution, is a certificate of secondary education, vocational or professional training [10].

Education within state higher education institutions can be free of charge as well as on a fee-paying basis. Prior to entering the Bologna process, the higher education system of Belarus was intended for five years of education for the majority of professions granting the certificate of a professional. The grading system was on a 10-point scale. The curriculum included a list of compulsory courses and the amount of hours required for each course. To evaluate postgraduate research, an academic assessment procedure is used with award of scientific degrees of Candidate of Sciences and Doctor or Sciences (higher doctorate).

\section{Belarus AND THE Bologna Process}

In spring 2015, Belarus joined the Bologna process under the condition to reform their higher education system within three years in order to bring it closer to a European standard.

A step-by-step action plan is to be implemented by Belarus is provided in the so-called Roadmap [11]. During the next three years, Belarus needs to reform the national education system according to the main provisions of the Bologna declaration and make changes on a legislative level to the Code of Education. Belarus should provide the final report on implementing the requirements of the Roadmap at the conference of European Higher Education Area Ministers in 2018.

A higher education institution involved in ECTS needs to prepare a package of documents (information package), which would contain all the information on the education in this higher education institution. Package includes:

- Information on the higher education institution (name and address, dates of start and end of semesters, examination sessions and holidays, curriculum, data on department involved in ECTS; general profile of 
the institution; application procedure for members of the initiative);

- General practical information (rules and cost of accommodation; accommodation plan; infrastructure, e.g. libraries, computer centers, laboratories, medical facilities, recreational and sports facilities, etc.)

- Description of courses. For each course one needs specify the following: course name, brief description of the course, structure (lectures, practical lessons, etc.) and hours allocated for the course, courses timing, course grading in ECTS-grades, info on the course staff; requirements level, including background required; system and form of final assessment of the student knowledge (oral or written exams, tests, term papers, graduation papers, etc.) and their timing;

- Documents, which determine the application process, study contents and timing (Learning Agreement), transcript of records and other documents required to lodge and study in the accepting higher education institution.

In preparation to join the Bologna process within the last two years, Belarus carried out a number of higher education reforms. A system of credits was introduced in the universities. For Humanities, it is planned to replace fiveyear higher education and a certificate of a professional with a four-year education and a Bachelor's degree, which is followed by a two-year Master's degree. This will ensure transfer onto European two-stage education. For the most complicated technical professions, it is supposed to retain five-year education with a certificate of a professional. Following, they can continue education for a year to pursue a Master's degree. For learners who want to pursue career in research and for those having the Candidate of Sciences, the degree will be treated as a European PhD. When getting a job abroad, Candidates of Sciences as they choose will receive a certificate of a $\mathrm{PhD}$ degree.

The Bologna process ensures significantly more independence by higher education institutions than that of the existing system. The new education code must legally encompass student self-governance, academic freedom, university autonomy that complies with global and European tendencies. A new concept of higher education provides wider opportunities to invite lecturers from other universities, including foreign ones. Standardization of curriculum and proper standards, in general, will allow Belarusian students get courses taken abroad awarded. The duration of mandatory work or study placements for professors and learners will be determined by universities. Active involvement of universities in European programs are planned.

After carrying out an educational reform, the country accepts commitment to issue free of charge European Diploma Supplements to Bachelor's and Master's degrees for all the graduates from higher education institutions. Official transcript includes a list of disciplines the learner studied, their hours and grades for each discipline.

\section{REFERENCES}

[1] Joint declaration on harmonisation of the architecture of the European higher education system. [pdf]. Available at: http://www.ehea.info/Uploads/Declarations/SORBONNE_DECLAR ATION1 [Accessed 10 October 2015].

[2] The Bologna Declaration of 19 June 1999.Available at: http://www.ond.vlaanderen.be/hogeronderwijs/bologna/documents/m dc/bologna_declaration1.pdf [Accessed 10 October 2015].

[3] Bologna Process - European Higher Education Area Available at: http://www.ehea.info/ [Accessed 10 October 2015]

[4] ESU (The European Students' Union), 2014. Student Advancement of Graduates Employability: Employability With Students' Eyes. [pdf]. Available at: http://www.sage.esuonline.org/SAGE+results+and+publications [Accessed 11 November 2014].

[5] European Commission/EACEA/Eurydice, 2013. Staff Mobility in Higher Education: National Policies and Programmes. Eurydice Overview. [pdf] Available at: http://eacea.ec.europa.eu/education/eurydice/focuson/documents/156EN.pdf [Accessed 26 October 2014]

[6] European Commission/EACEA/Eurydice, 2015. The European Higher Education Area in 2015: Bologna Process Implementation Report. Luxembourg: Publications Office of the European Union.

[7] Decree No. 21 of Ministry of Education of the Republic of Belarus dated May 24, 2002 on Introduction of ten-point grading system for the assessment of the performance of learners in institutions of secondary education and technical training.

[8] Credit and rating system and ECTS grading system. Availableat: http://uu.kventz.ru/ects/ [Accessed 10 October 2015].

[9] Regulations on the performance appraisal rating system in Belarusian State University. Approved by the Order of Rector of BSU No. 382OD dd. August 18, 2015.

[10] Code of Education of the Republic of Belarus. January 13, 2011. No. 243-3.

[11] Belarus Roadmap for Higher Education Reform. Available at: http://bolognaby.org/?attachment_id=2121[Accessed 10 October 2015]. 